\title{
Purification of $\mathbf{F}_{1}$-ATPase from cuckoo-pint (Arum maculatum) mitochondria
}

\author{
A comparison of subunit composition with that of rat liver $F_{1}-\mathbf{A T P a s e}$
}

\author{
Paul P. J. DUNN,* Antoni R. SLABAS $\dagger$ and Anthony L. MOORE* $\ddagger$ \\ *Department of Biochemistry, University of Sussex, Falmer, Brighton BN1 9QG, Sussex, U.K., and $\dagger$ Applied \\ Biosciences, Unilever Research, Colworth House, Sharnbrook, Beds. MK44 ILO, U.K.
}

(Received 3 October 1984/Accepted 30 November 1984)

\begin{abstract}
Plant mitochondrial ATPase has been chloroform-solubilized and purified by gel filtration from spadices of cuckoo-pint (Arum maculatum). The subunit composition of purified plant and rat liver ATPase were compared by sodium dodecyl sulphate/polyacrylamide-gel electrophoresis. The $\delta$ - and $\varepsilon$-subunits of the plant enzyme are larger than their supposed rat liver counterparts and, as such, $A$. maculatum mitochondrial ATPase shows structural homologies with the enzyme from Escherichia coli [Futai, Sternweis \& Heppel (1974) Proc. Natl. Acad. Sci. U.S.A. 71, 2725-2729] rather than with the rat liver enzyme.
\end{abstract}

The catalytic portion, or $F_{1}-A T P a s e$, of the ATPase complex of mitochondria and bacteria has been purified from a range of animal tissues and yeast (Criddle et al., 1979) and from Escherichia coli (Futai et al., 1974). In most cases, purified $\mathrm{F}_{1}$ ATPases have been shown to consist of five detergent-separable subunits which have generally been termed $\alpha, \beta, \gamma, \delta$ and $\varepsilon$ in decreasing order of $M_{\mathrm{r}}$. However, it has previously been shown, by subunit-size and amino-acid-sequence analysis, that the subunits of $E$. coli and ox heart $F_{1}$ ATPases are not necessarily equivalent (Walker $e t$ al., 1982). Most strikingly, E. coli $\delta$-subunit was found to be equivalent to oscp of ox heart $F_{0^{-}}$ ATPase rather than the subunit of ox heart $F_{1}$ ATPase (Walker et al., 1982).

Thus far there has been little research on the $F_{1}$ ATPase of higher-plant mitochondria. Recently, however, sweet-potato (Ipomoea batatas) $\mathrm{F}_{1}-\mathrm{AT}$ Pase has been purified by an elaborate four-step procedure from submitochondrial particles (Iwasaki \& Asahi, 1983). This enzyme consisted of six subunits. In contrast, we report here a rapid twostep purification of five-subunit $F_{1}-A T P a s e$ from Arum maculatum (cuckoo-pint) submitochondrial particles. The same procedure was used for

Abbreviations used: $F_{1}-A T P a s e$, catalytic portion of the proton-translocating ATPase insensitive to oligomycin: $F_{0}$-ATPase, membrane sector or ionophore portion of the ATPase; SDS, sodium dodecyl sulphate; PMSF, phenylmethanesulphonyl fluoride.

$\ddagger$ To whom correspondence and reprint requests should be sent. purification of rat liver $F_{1}$-ATPase to enable a direct comparison of subunit composition. The results presented show that, on the basis of $M_{\mathrm{r}}$, the subunits of $A$. maculatum $\mathrm{F}_{1}-\mathrm{ATPase}$ are more analogous to those of $E$. coli $\mathrm{F}_{1}-\mathrm{ATPase}$ than to those of rat liver $F_{1}$-ATPase.

\section{Experimental}

Mitochondria were isolated from locally collected spadices of Arum maculatum (cuckoo-pint) as described previously (Moore \& Proudlove, 1983) and were stored at $-80^{\circ} \mathrm{C}$. Mitochondria were also prepared from rat liver by the method of Johnson \& Lardy (1969) and were stored likewise. Submitochondrial particles were prepared by using an Aminco French pressure cell as described by Moore \& Proudlove (1983) and stored at $-80^{\circ} \mathrm{C}$ until use. $F_{1}$-ATPase was released from submitochondrial membranes with chloroform as described by Dunn et al. (1984). A. maculatum and rat liver $F_{1}$-ATPases were subsequently purified as follows. Ultrogel AcA34 (LKB, South Croydon, Surrey, U.K.) was degassed and then used to make a $2.6 \mathrm{~cm} \times 90 \mathrm{~cm}$ column, which was equilibrated with $20 \mathrm{~mm}$-Tris $/ \mathrm{HCl}(\mathrm{pH} 7.7) / 50 \mathrm{~mm}-\mathrm{NaCl} / 1 \mathrm{~mm}$ EDTA/1 mM-ATP/0.5 mM-PMSF. The column was calibrated with Blue Dextran (void volume $134 \mathrm{ml}$ ) and the following molecular-mass standards (obtained from Sigma Chemical Co. Ltd., Poole, Dorset, U.K.): thyroglobulin $(669 \mathrm{kDa})$, ferritin $(440 \mathrm{kDa})$, catalase $(232 \mathrm{kDa})$, aldolase $(158 \mathrm{kDa})$. ATPase released by chloroform treat- 
ment (6mg) was applied to the column and proteins were eluted with the equilibration buffer at a flow rate of $28 \mathrm{ml} / \mathrm{h}$. Fractions $(2.8 \mathrm{ml})$ were collected and assayed for ATPase activity by using the ATP-regenerating system of Pullman et al. (1960). Active factions were pooled, dialysed extensively against equilibration buffer minus $\mathrm{NaCl}$, and freeze-dried for subsequent analysis by polyacrylamide-gel electrophoresis. Protein was assayed by $A_{280}$ or by the method of Peterson (1977). 'Native' (i.e. non-SDS) polyacrylamide-gel electrophoresis was performed on slab gels with a linear polyacrylamide concentration gradient from 5 to $10 \%(\mathrm{w} / \mathrm{v})$ as described by Knowles \& Penefsky (1972), except that the ratio $(w / w)$ of acrylamide to bisacrylamide was $75: 4$ and that sucrose, Tris and EDTA were omitted from the acrylamide/bisacrylamide stock. Subunit structure was analysed by electrophoresis on $12.5 \%-(\mathrm{w} / \mathrm{v})$ polyacrylamide gels containing $0.1 \%$ SDS (Laemmli, 1970). Gels were silver-stained for protein as described by Morrissey (1981). SDS/polyacrylamide gels were calibrated with the following molecular-mass standards (purchased from Sigma): bovine serum albumin $(68 \mathrm{kDa})$, ovalbumin $(43 \mathrm{kDa}), \quad \alpha$-chymotrypsinogen $(25.7 \mathrm{kDa})$, cytochrome $c(11.7 \mathrm{kDa})$. Densitometer scans of polyacrylamide gels were obtained with a Joyce-Loebl microdensitometer. Aurovertin fluorescence of protein released by chloroform treatment was observed by the method of Beechey et al. (1975). Aurovertin B was kindly donated by Professor R. B. Beechey (University of Aberystwyth, Aberystwyth, Dyfed, Wales, U.K.).

\section{Results and discussion}

The densitometer scan of a native polyacrylamide gel (Fig. 1a) shows that one major protein and six to seven minor proteins were released with chloroform from $A$. maculatum submitochondrial membranes, as judged by silver staining. Beechey et al. (1975) utilized chloroform to solubilize ox heart $F_{1}$-ATPase to near homogeneity. However, in this case, the less sensitive Coomassie Blue stain was used to reveal proteins (Beechey et al., 1975). When proteins released by chloroform were treated with aurovertin B before electrophoresis, the antibiotic bound to the major protein, as revealed by the fluorescent band shown in Fig. $1(b)$. Aurovertin forms a fluorescing complex with solubilized ox heart (Beechey et al., 1975) and rat liver (Lardy \& Lin, 1969) mitochondrial ATPases. Fig. $1(b)$ shows that solubilized plant mitochondrial ATPase also produces a fluorescent complex with aurovertin. The specific activity of $A$. maculatun $\mathrm{F}_{1}$-ATPase released by chloroform was 2.3 units $/ \mathrm{mg}$ of protein ( 1 unit $=1 \mu \mathrm{mol}$ of ATP

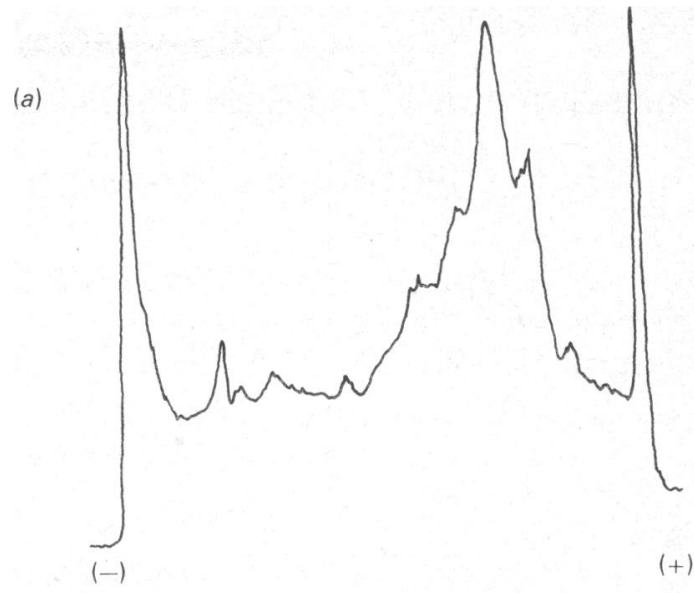

(b)

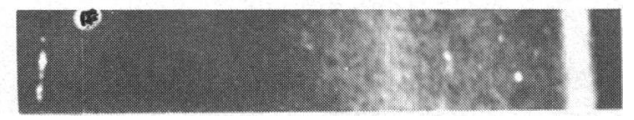

Fig. I. Electrophoresis of A. maculatum chloroformreleased proteins on 'natice' polyacrylamide gels

The gels were 5-10\%-(w/v)-polyacrylamide slab gels, silver-stained and scanned (to show protein bands) with a Joyce-Loebl microdensitometer $(a)$; $\cdot(-)$ ' is the origin and ' $(+)^{\prime}$ ' the dye front. In $(b)$, chloroform-released protein $(2 \mu \mathrm{g})$ was incubated with $10 \mathrm{nmol}$ of aurovertin B at $39^{\circ} \mathrm{C}$ for $15 \mathrm{~min}$ before electrophoresis and ATPase-associated fluor: escence was observed by the method of Beechey $e t$ al. (1975).

hydrolysed/min per $\mathrm{mg}$ of protein), whereas that for rat liver $F_{1}$-ATPase prepared in the same manner was 11.6 units $/ \mathrm{mg}$ of protein. For both enzymes this represents a recovery of $75 \%$ of total enzyme units from submitochondrial-particle ATPase activity. Initial ATPase activities were 0.21 and 1.34 units $/ \mathrm{mg}$ for $A$. maculatum and rat liver submitochondrial particles respectively.

Fig. 2 shows the elution profile for gel-filtration purification of $A$. maculatum $\mathrm{F}_{1}$-ATPase. Plant mitochondrial $F_{1}$-ATPase was purified to homogeneity, as revealed by 'native' polyacrylamide-gel electrophoresis. The purified enzyme had a specific activity of 30 units $/ \mathrm{mg}$, which is equivalent to a 140-fold purification from submitochondrial ATPase activity, and a recovery of $50 \%$ of the total enzyme units. The elution volume from the calibrated gel-filtration column was $202 \mathrm{ml}$, indicating that $A$. maculatum $\mathrm{F}_{1}-\mathrm{ATPase}$ has an $M_{\mathrm{r}}$ of 386000 . Similarly, Iwasaki \& Asahi (1983) reported an $M_{\mathrm{r}}$ of 370000 and specific 


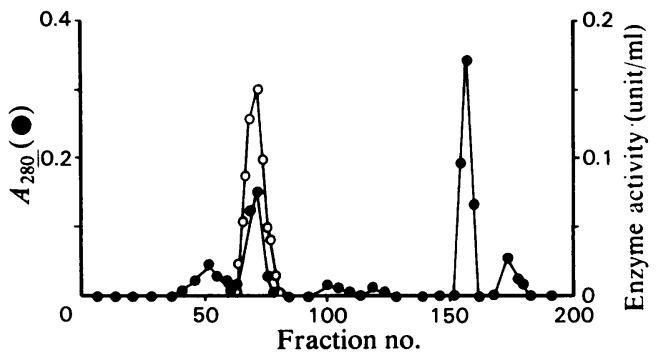

Fig. 2. Chromatography of chloroform-released proteins on Ultrogel AcA34

A. maculatum chloroform-released proteins $(6 \mathrm{mg})$ were applied to the gel-filtration column, which was equilibrated in, and eluted with, $20 \mathrm{~mm}-\mathrm{Tris} / \mathrm{HCl}$ (pH 7.7)/50 mM-NaCl/1 mM-EDTA, 0.5 mM-PMSF. , Protein (detected by absorbance at $280 \mathrm{~nm}$ ); $\bigcirc$, Enzyme activity [units ( $\mu \mathrm{mol}$ of ATP hydrolysed $/ \mathrm{min}) / \mathrm{ml}$ ].

activity of 39 units $/ \mathrm{mg}$ for the purified sweetpotato $F_{1}-A T P a s e$, although this represents only a $30 \%$ recovery of enzyme units and 7 -fold purification. The $\mathrm{F}_{1}$-ATPase released by chloroform from rat liver was also purified to homogeneity by gel filtration on Ultrogel AcA34 (results not shown). Purified rat liver $\mathrm{F}_{1}$-ATPase had a specific activity of 85 units $/ \mathrm{mg}$ (60-fold purification and $65 \%$ recovery of total enzyme units) and, with an elution volume of $200 \mathrm{ml}$ from the gel-giltration column, an $M_{\mathrm{r}}$ of approx. 396000 . The $M_{\mathrm{r}}$ values reported here for purified plant and rat liver $F_{1}$-ATPases are similar to those previously reported for mitochondrial and bacterial $F_{1}-A T P a s e s$ (Penefsky, 1979).

The subunit compositions of purified A. maculatum and rat liver $\mathrm{F}_{1}-\mathrm{ATPases}$ were analysed by SDS/polyacrylamide-gel electrophoresis (Figs. $3 a$ and $3 b$ ). Silver staining for protein by the method of Morrissey (1981) revealed four subunits for each enzyme, which we have designated as $\alpha, \beta, \gamma$, and $\delta$ according to established nomenclature. For Arum maculatum $\mathrm{F}_{1}$-ATPase the subunit molecular masses are $5 \mathrm{kDa}(\alpha), 52 \mathrm{kDa}(\beta), 35 \mathrm{kDa}(\gamma)$, $22 \mathrm{kDa}(\delta)$ (Fig. $3 a$, whereas for rat liver the calculated values are $553 \mathrm{kDa}(\alpha), 51 \mathrm{kDa}(\beta)$, $33 \mathrm{kDa}(\gamma)$, and $12 \mathrm{kDa}(\delta)$ (Fig. $3 b)$. A fifth subunit

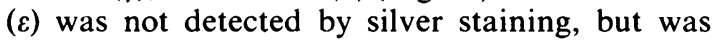
visible when Coomassie Blue protein staining was used. It would therefore appear that the silverstaining technique used in the present study does not stain the $\varepsilon$-subunit of $F_{1}$-ATPases. Rat liver $\varepsilon$ subunit has a molecular mass of $7.5 \mathrm{kDa}$, whereas the subunit from $A$. maculatum is slightly larger at $11 \mathrm{kDa}$ (P. P. J. Dunn, unpublished work). Iwasaki \& Asahi (1983) reported similar subunit molecular masses for sweet-potato $F_{1}$-ATPase, although two
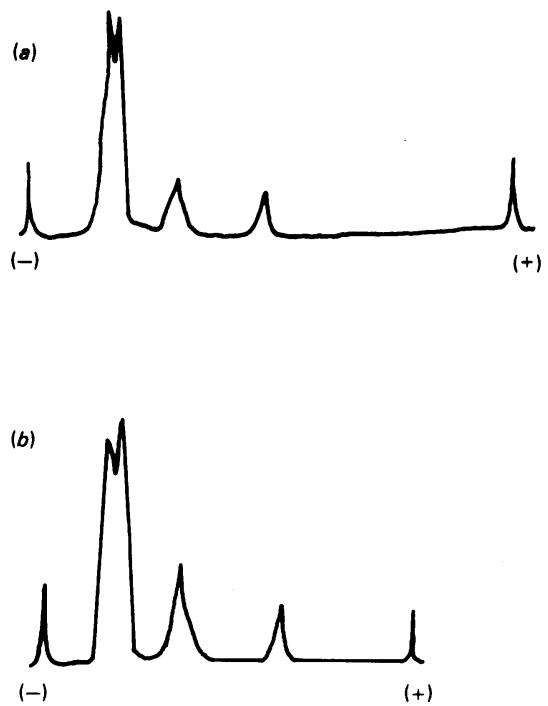

Fig. 3. Subunit analysis of plant and animal $F_{1}-A T P a s e$ Subunit analysis of $A$. maculatum $(2 \mu \mathrm{g})(a)$ and rat liver $(2 \mu \mathrm{g})(b) \mathrm{F}_{1}$-ATPases was performed on $12.5 \%$ $(\mathrm{w} / \mathrm{v})$ polyacrylamide slab gels, containing $0.1 \%$ SDS, silver-stained for protein and scanned with a Joyce-Loebl microdensitometer; ' $(-)$ ' is the origin and ' $(+)$ ' the dye front.

$\delta$-subunits $\left(\delta\right.$ and $\left.\delta^{\prime}\right)$ were apparently present. Those authors suggest that one of the $\delta$-subunits $\left(\delta^{\prime}\right)$ may have arisen from proteolytic digestion. The results shown in Fig. 3(b) for the subunit composition of rat liver $F_{1}$-ATPase concur favourably with those published previously for animal $F_{1}$ ATPases (Criddle et al., 1979). The three largest subunits of $A$. maculatum $\mathrm{F}_{1}$-ATPase $(\alpha, \beta$ and $\gamma)$ are nearly identical in size with those of rat liver $F_{1}$-ATPase. There is, however, a considerable discrepancy between the molecular masses of the $\delta$-subunits, the plant $\delta$-subunit being $10 \mathrm{kDa}$ larger than the rat liver $\delta$-subunit $(22 \mathrm{kDa}$ as compared with $12 \mathrm{kDa}$ respectively). On the whole, the purified plant $F_{1}$-ATPase described here, displays a subunit composition very similar to that reported for $E$. coli $\mathrm{F}_{1}-\mathrm{ATPase}$ by Futai et al. (1974). The molecular masses of $E$. coli $\delta$ - $(20.5 \mathrm{kDa})$ and $\varepsilon-$ $(12 \mathrm{kDa})$ subunits (determined by SDS/polyacrylamide-gel electrophoresis; Futai et al., 1974) show close similarity with $\delta$ - $(22 \mathrm{kDa})$ and $\varepsilon^{-}(11 \mathrm{kDa})$ subunits from $A$. maculatum $\mathrm{F}_{1}-\mathrm{ATPase}$ (see Fig. 3). Walker et al. (1982) have shown, by amino-acidsequence analysis, that $E$. coli and ox heart $\delta$ subunits are not equivalent. Ox heart $\delta$-subunit is homologous in sequence with the $\varepsilon$-subunit of $E$. coli, whereas the $E$. coli $\delta$-subunit shows sequence and function homologies with ox heart oscp

Vol. 225 
(Walker et al., 1982). If $\delta$ - and $\varepsilon$-subunits of plant and bacterial $F_{1}$-ATPases also show sequence and function, as well as size, homologies, then important answers may be found for the evolutionary development of mitochondria in higher plants and animals.

This research was supported by a Science and Engineering Research Council (SERC) grant to A. L. M., a SERC CASE (Co-operative Awards in Science and Engineering) studentship to P. P. J. D., and by a grant from Unilever Research. We are indebted to Dr. J. E. Walker (MRC Molecular Biology Laboratory, Cambridge) for helpful advice on purification procedures.

\section{References}

Beechey, R. B., Hubbard, S. A., Linnett, P. E., Mitchell, A. D. \& Munn, E. A. (1975) Biochem. J. 148, 533-537 Criddle, R. S., Johnston, R. F. \& Stack, R. J. (1979) Curr. Top. Bisenerg. 9, 89-145

Dunn, P. P. J., Slabas, A. R., Cottingham, I. R. \& Moore, A. L. (1984) Arch. Biochem. Biophyss. 229, 287 294
Futai, M., Sternweis, P. C. \& Heppel, L. A. (1974) Proc. Natl. Acad. Sci. U.S.A. 71, 2725-2729

Iwasaki, Y. \& Asahi, T. (1983) Arch. Biochem. Biophys. 227, 164-173

Johnson. D. \& Lardy, H. A. (1969) Methods Enzymol. 10, 9496

Knowles, A. F. \& Penefsky, H. S. (1972) J. Biol. Chem. 247, 6617-6623

Laemmli, U. K. (1970) Nature (London) 277, 680-685

Lardy, H. A. \& Lin, C. H-.C. (1969) in Inhibitors, Tools in Cell Research (Bucher, T. \& Sies, H. M., eds.), pp. 279 280, Springer Verlag, Berlin

Moore, A. L. \& Proudlove, M. (1983) in Isolation of Membranes and Organelles from Plant Cells (Hall, J. L. \& Moore, A. L., eds.), pp. 153 184, Academic Press, London

Morrissey, J. H. (1981) Anal. Biochem. 117, 307-310

Penefsky, H. S. (1979) Adr. Enzlimol. Relat. Areas Mol. Biol. 49, 223-280

Peterson, G. L. (1977) Anal. Biochem. 83, 346-356

Pullman, M. E., Penefsky, H. S., Datta, A. \& Racker, E. (1960) J. Biol. Chem. 235, 3322-3329

Walker, J. E., Runswick, M. J. \& Saraste, M. (1982) FEBS Lett. 146, 393-396 